\title{
Cytotoxic and Apoptotic Effects of the Venom of the Scorpion Heterometrus liangi in Human KYSE-510 Cells (Esophageal cancer)
}

\author{
Li Qinjing $^{\#}$ \\ College of bioscience and biotechnology, Hunan \\ Agriculture University \\ Changsha, China \\ Xiao Kaifu \\ College of bioscience and biotechnology, Hunan \\ Agriculture University \\ Changsha, China
}

\begin{abstract}
Scorpion venom is usually utilized to induce cancer cell death via apoptosis pathways. Our study focuses on the effects of the Heterometrus liangi scorpion venom on the proliferation of KYSE-510 cells (human esophageal cancer cells) and its related molecular mechanism. Marked morphological changes in KYSE-510 cells after treatment with scorpion venom were observed using scanning electron microscopy (SEM) and transmission electron microscopy (TEM). Cell apoptosis were determined using flow cytometry (FCM). Moreover, RT-PCR and Western blot analysis was used to investigate the different levels of p21 and caspase-3 expression. Our results showed that scorpion venom at concentrations of $50-100 \mathrm{ug} / \mathrm{mL}$ caused dose-dependent inhibition of KYSE-510 cell proliferation. And, the ratio of apoptosis and necrosis increased. Besides, the effect of venom treated in KYSE-510 cells in p21 gene expression was reinforced, but the caspase-3 gene expression had indistinctive effect. The levels of p21 and caspase-3 protein expression were up-regulated after scorpion venom treatment. Therefore, scorpion venom may increase the expressions of $\mathrm{p} 21$ and caspase-3 protein to inhibite KYSE-510 proliferation and induce cell apoptosis selectively.
\end{abstract}

Keywords-KYSE-510 cells; gene expression; cell proliferation; cytotoxicity; Heterometrus liangi venom

\section{INTRODUCTION}

Utilizing potential biochemical and biological molecules to target neoplastic tumors has emerged as one of alternative approaches in cancer research. One kind of promising biochemical and biological molecules is found in scorpion's venom [1]. In Chinese traditional medical practice, Buthus martensii Karsch venom has been used as a traditional Chinese medicine to treat various ailments for more than 2000 years [2]. Scorpion venoms contain different groups of compounds such as proteins (including

\author{
Wang Zhi** \\ College of bioscience and biotechnology, Hunan \\ Agriculture University \\ Changsha, China \\ wangzspider@sina.com \\ **The corresponding authors \\ \# co-first author
}

several enzymes like hyaluronidases, phospholipases, sphingomyelinases) [3], and small molecular weight peptides with wide pharmacological activities such as anti-epileptic [4] and antimicrobial [5]. Recent studies have shown that some scorpion venoms have direct inhibitory effects on tumor cells and could effectively lead to cancer cell apoptosis. For example, venom of Buthus martensii Karsch was able to inhibit glioma tumour growth [6]. Furthermore, scorpion venoms have been reported to hamper proliferation of prostate cancer cells [7], human leukemia cells [8] and human neuroblastoma [9]. They have also been shown to play a significant role in enhancing immunity. Thus, scorpion venom have great potential to be used as ideal anticancer drugs [10-13].

The composition of scorpion venoms and effectiveness of venoms in inhibiting cancer cell proliferation depend on multiple factors, including genus and species, geographic origin and age of the scorpion, its physiological state, etc. The scorpion Heterometrus liangi is mainly (or only) distributed in southern Vietnam [14] and there is no reported investigation on the venom of this species. In the present study, the effects of venom of the scorpion H. liangi on KYSE-510 cell (Esophageal cancer) growth and proliferation were investigated and its possible mechanisms were explored.

\section{MATERIALS AND METHODS}

A. Reagents

RPMI-1640 (Gibco Laboratories, Grand Island, NY, USA) dissolved in double distilled water with the $\mathrm{pH}$ value adjusted to 7.0 using $\mathrm{NaHCO} 3$, was disinfected and stored at - $20{ }^{\circ} \mathrm{C}$. Fetal calf serum (FCS) (Gibco Laboratories, made in Uruguay, NY, USA) was sterilized and stored at $-20{ }^{\circ} \mathrm{C}$. Verapamil, streptomycin, penicillin and $0.5 \%$ hydrocortisone were purchased from North China Pharmaceutical Company (Shijiazhuang, China). Propidium iodide (PI), bovine serum albumin (BSA), and Triton X-100 were purchased from Sigma Company (St 
Louis, MO, USA). The rabbit polyclonal anti-body against caspase-3 and p21 rodamine labeled secondary antibody was purchased from MILLIPORE (MILLIPORE, USA).

\section{B. scorpion venom}

Pure scorpion venom was collected from $\mathrm{H}$. liangi by electrical stimulation of 20 scorpion (the weight of each scorpion was approximately $100 \mathrm{~g}$ ). The scorpion venom was dissolved in $1 \mathrm{mM}$ ( $\mathrm{pH}$ 7.2) phosphate buffered saline (PBS) and centrifuged at $8000 \times \mathrm{g}$ for $10 \mathrm{~min}$ to remove insoluble materials. The spider venom was freeze-dried and stored at $-20 \mathrm{oC}$ until use.

\section{Cell Culture}

KYSE-510 cells were cultured in a standard medium consisted of RPMI-1640 medium supplemented with $10 \%$ heat-inactivated FCS, $2 \mathrm{mM}$ L-glutamine, $100 \mathrm{U} / \mathrm{mL}$ streptomycin and $100 \mathrm{U} / \mathrm{mL}$ penicillin. Cells were kept in a humidified incubator (Thermo Forma) aerated with 5\% $\mathrm{CO}_{2}$ in air at $37{ }^{\circ} \mathrm{C}$. Cells in the log growth phase were used in the experiments described below [16].

MTT assay: The inhibition of cell proliferation was assessed by MTT (Sigma Chemical Co., USA) assay. Cells were cultured in a 96-well plate at a density of $2 \times 10^{4}$ cells per well and incubated overnight [17]. Medium was discarded and cells were exposed to different concentrations of scorpion venom $(12.5,25,50$, and $100 \mu \mathrm{g} / \mathrm{mL}$ ). Following $24 \mathrm{~h}$ and $48 \mathrm{~h}$ incubation, 20 $\mu \mathrm{L}$ of MTT stock solution $(5 \mathrm{mg} / \mathrm{mL})$ was added to each well. After $4 \mathrm{~h}$ incubation, the supernatants were aspirated and the formazan precipitates were solubilized by addition of $150 \mu \mathrm{L}$ per well of dimethylsulfoxide (DMSO). Following $30 \mathrm{~min}$ of incubation in dark at room temperature, absorbance was determined at $570 \mathrm{~nm}$ by an ELISA reader (Thermo Labsystems, USA).

\section{Microscopic observation of morphology}

KYSE-510 cells were subcultured on slides in 6-well plates with $5 \times 10^{4}$ cells/well. After different concentration of venom $(0,50$ and $100 \mu \mathrm{g} / \mathrm{mL})$ treatment for $24 \mathrm{~h}$, the cells were washed with $0.01 \mathrm{M}$ (pH 7.2) PBS and observed under an inverted phase contrast microscope (Olympus LH-50A, Japan).

\section{E. Specimens for electron microscopy}

KYSE-510 cells in the exponential phase were used and cultivated with various concentrations of scorpion venom for $24 \mathrm{~h}$. The cells were harvested and fixed with $25 \mathrm{~mL} / \mathrm{L}$ glutaraldehyde in 0.1 M PBS ( $\mathrm{pH}$ 7.2) for $2 \mathrm{~h}$ at $4{ }^{\circ} \mathrm{C}$. For SEM examination, the specimens were post-fixed for $1 \mathrm{~h}$ in $2 \% \mathrm{OsO}_{4}$, dehydrated by adding a series of graded ethanol solutions to the filtration system and then slowly dried over the course of $24 \mathrm{~h}$ by evaporation. The filter was removed from the filtration apparatus and mounted on an aluminum stub, and then the cells were gold sputter coated. Specimens were examined with a STEREOSCAN 260 SEM at $20 \mathrm{kV}$. For TEM examination, cells corresponding to each population were collected in Haemoline (BioChem Pharma, Allentown, PA, USA), transferred to microcentrifuge tubes, pelleted, and fixed in $1 \% \mathrm{OsO}_{4}$ (in distilled $\mathrm{H}_{2} \mathrm{O}$ ). A total of
$4 \times 10^{7}$ cells were sorted to collect $2 \times 10^{6}$ cells representative of each of the individual populations. After dehydration through a series of graded alcohol and propylene oxide solutions, the cells were infiltrated with Epon (epoxy resin) and polymerized. Ultra-thin sections were cut, recovered on form varcoated copper grids, stained with uranyl acetate and lead citrate, and then examined with a H-7500 transmission electron microscope (HITACHI, Japan) operated at $65 \mathrm{kV}$.

\section{F. Annexin V-FITC and PI double staining analysis by FCM}

For confirmation of apoptosis induced by Scorpion venom, measurement of externalization of PS, an early event during apoptosis, by double staining with Annexin V-FITC (fluorescein isothiocyanate) and PI (Propidiumiodide) was performed [18]. The specification of Annexin V-FITC Apoptosis Detection Kit with PI (Bestbio, Shanghai) was operated as described in the manufacturer's instruction. Human umbilical vein endothelial cell line (HUVEC-21) was used as a control group to estimate effects of venom on normal cells.

\section{G. RT-PCR}

Total RNA was extracted by using TRIzol reagent (Gibco, Inc.). RNA quality and quantity was determined by ultra-violet (UV) spectrophotometry and $1.0 \%$ agarose gel electrophoresis. About $300 \mathrm{ng}$ of total RNA was reversely transcribed using a Super S with Platinum Taq kit (Fermentase, Inc.) with the following conditions: $94 \mathrm{oC}$ for $2 \mathrm{~min}$, followed by 30 cycles of $94 \mathrm{oC}$ for $25 \mathrm{~s}$, $55 \mathrm{oC}$ for $15 \mathrm{~s}$, and $72 \mathrm{oC}$ for $40 \mathrm{~s}$. PCR reaction was completed by incubation for $5 \mathrm{~min}$ at $72 \mathrm{oC}$. RT-PCR products were then separated on a $1.0 \%$ agarose gel, visualized under UV light and photographed. GAPDH was served as an internal control.

\section{H. Western blot assay}

KYSE-510 cells treated with different concentrations of the scorpion venom $(0,50,100$ and $200 \mu \mathrm{g} / \mathrm{mL})$ were incubated respectively at $5 \times 106$ cells/well for $48 \mathrm{~h}$, followed by a further cultivation for $48 \mathrm{~h}$ with $1 \mathrm{~mL}$ of serum-free RPMI-1640 medium. Proteins of the cells were isolated by lysis buffer [100 mM Tris- $\mathrm{HCl}, \mathrm{pH} 6.8$, $4 \%$ (W/V) SDS, $20 \%$ (V/V) glycerol, $200 \mathrm{mM}$ $\beta$-mercaptoethanol, PMSF $1 \mathrm{mM}$, aprotinin $1 \mathrm{mg} / \mathrm{mL}$, Sigma] and measured by using the Bradford assay with Bio-Photometer (Biophotometer 6131 GB/HK, Eppendorf) at $595 \mathrm{~nm}$. Equal amount of proteins in each sample was resolved in $10 \%$ SDS-PAGE and transferred onto nitrocellulose membranes. After blocking with 10 $\mathrm{mL} / \mathrm{L}$ fat-free milk, the membranes were incubated with the appropriate dilution of rabbit polyclonal p21 antibody, caspase- 3 and $\beta$-Actin antibody overnight at $40{ }^{\circ} \mathrm{C}$. Then, the membranes were washed 3 times with PBS and incubated with a horseradish peroxidase conjugated secondary antibody (Acta Physiologica Sinica). Proteins were detected by using the enhanced chemilumine scence (ECL) kit according to the manufacturer's protocol (Amersham, Buckinghamshire, UK). 


\section{Statisticalanalysis}

SPSS software was used to analyze means of all results. Student's t test was performed for intergroup comparison. $\mathrm{P}<0.05$ was considered to be statistically significant.

\section{RESULT}

\section{A. Cell proliferation inhibition assessed by MTT assay}

Dose-dependent inhibition of KYSE-510 cells by the scorpion venom at $24 \mathrm{~h}$ and $48 \mathrm{~h}$ post incubation was observed. IC50 for $24 \mathrm{~h}$ is $50 \mu \mathrm{g} / \mathrm{mL}$ and $34.5 \mu \mathrm{g} / \mathrm{mL}$ for $48 \mathrm{~h}$. When the concentration ranged from 10 to 100 $\mu \mathrm{g} / \mathrm{mL}$, the inhibitory effect was dose-dependent (TABLE I). Besides, the inhibitory effect of venom on cell growth also is dose-dependent and statistically significant (Fig .1) $(\mathrm{p}<0.05)$.

TABLE I. INHIBITION OF CELL PROLIFERATION BY THE SCORPION VENOM

\begin{tabular}{|c|c|c|c|}
\hline \multirow{2}{*}{\multicolumn{2}{|c|}{ Group/ $\mu \mathrm{g} \cdot \mathbf{m L - 1}$}} & \multicolumn{2}{|c|}{ Growth inhibitory rate $(\%)$} \\
\hline & & $24 h$ & $48 h$ \\
\hline \multicolumn{2}{|l|}{ Negative control } & 0 & 0 \\
\hline \multirow{4}{*}{ Scorpion venom } & 12.5 & $8.75 \pm 1.51 *$ & $9.15 \pm 0.97 *$ \\
\hline & 25 & $18.05 \pm 2.48 *$ & $21.03 \pm 1.30 *$ \\
\hline & 50 & $25.63 \pm 4.03 *$ & $28.54 \pm 1.78 *$ \\
\hline & 100 & $30.74 \pm 2.36 *$ & $34.68 \pm 0.46^{*}$ \\
\hline
\end{tabular}

Each datum point represents the mean \pm SD of three independent experiments. Significances indicated are compared to control. N.S (not significant), $* \mathrm{p}<0.05$

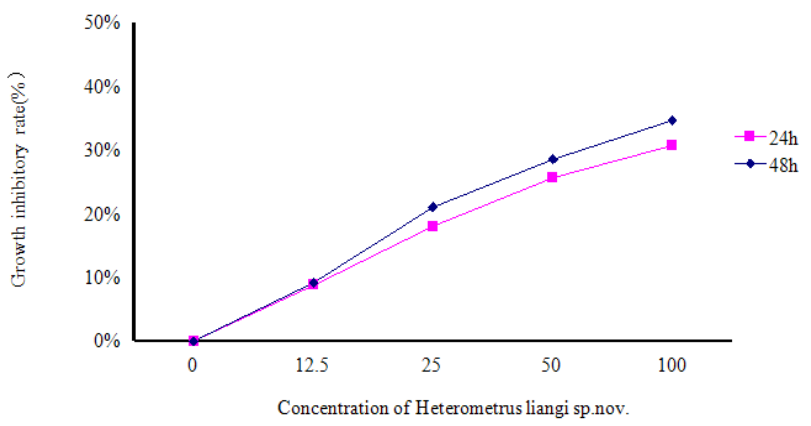

Figure 1. Inhibition of cell proliferation by venom in dose- and time-dependent manner

\section{B. Microscopic observation of morphology}

After incubation with the venom for $48 \mathrm{~h}$, KYSE-510 cells showed morphologically cell death under an optical microscope (Fig .2). The cell number reduced significantly and the cells turned smaller, cytoplast more inspissate, and nuclear chromatin agglutinated more compared with the control group.
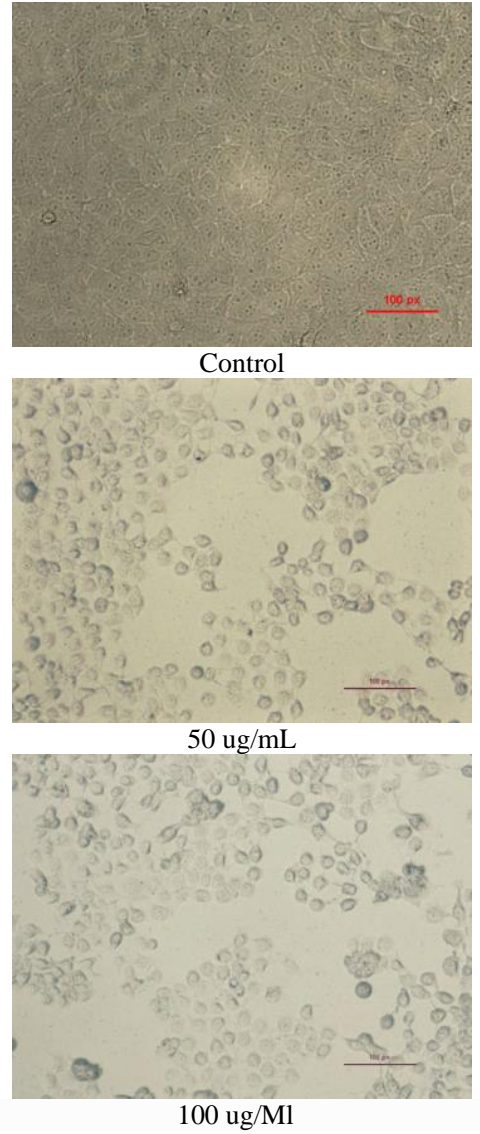

Figure 2. Morphology of KYSE-510 cells treated with different concentrations of the venom

\section{Morphological observations by SEM and TEM}

After treated with the scorpion venom for $48 \mathrm{~h}$, KYSE-510 cells had morphological features indicative of apoptosis as seen in the SEM images compared to the control cells (Fig .3A, 3B, 3C, 3D). In the control group, cell was actively growing and tightly connected, displaying irregular polygonal shape with the uplifted cell central. In addition, microvilli was extended to the surrounding, closely attached to the slide.

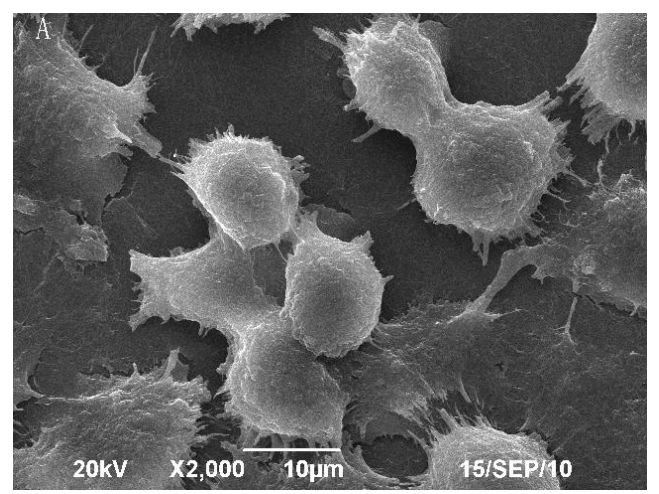



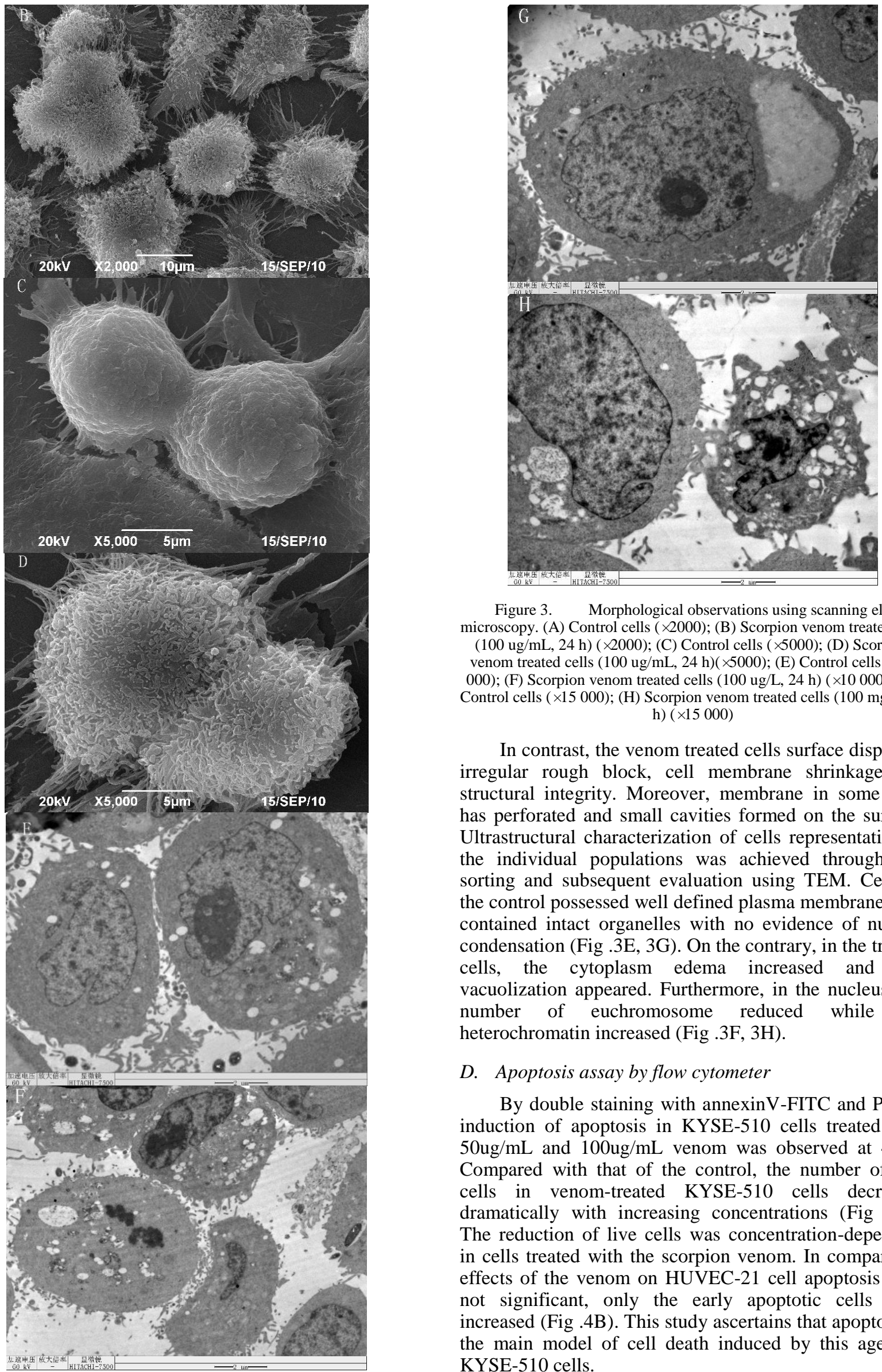

Figure 3. Morphological observations using scanning electron microscopy. (A) Control cells ( $\times 2000)$; (B) Scorpion venom treated cells (100 ug/mL, $24 \mathrm{~h})(\times 2000)$; (C) Control cells $(\times 5000)$; (D) Scorpion venom treated cells $(100 \mathrm{ug} / \mathrm{mL}, 24 \mathrm{~h})(\times 5000)$; (E) Control cells $(\times 10$ 000); (F) Scorpion venom treated cells (100 ug/L, 24 h) ( $\times 10000)$; (G) Control cells ( $\times 15$ 000); (H) Scorpion venom treated cells (100 mg/L, 24 h) $(\times 15000)$

In contrast, the venom treated cells surface displayed irregular rough block, cell membrane shrinkage and structural integrity. Moreover, membrane in some cells has perforated and small cavities formed on the surface. Ultrastructural characterization of cells representative of the individual populations was achieved through cell sorting and subsequent evaluation using TEM. Cells in the control possessed well defined plasma membranes and contained intact organelles with no evidence of nuclear condensation (Fig .3E, 3G). On the contrary, in the treated cells, the cytoplasm edema increased and cell vacuolization appeared. Furthermore, in the nucleus, the number of euchromosome reduced while the heterochromatin increased (Fig .3F, 3H).

\section{Apoptosis assay by flow cytometer}

By double staining with annexinV-FITC and PI, the induction of apoptosis in KYSE-510 cells treated with $50 \mathrm{ug} / \mathrm{mL}$ and $100 \mathrm{ug} / \mathrm{mL}$ venom was observed at $48 \mathrm{~h}$. Compared with that of the control, the number of live cells in venom-treated KYSE-510 cells decreased dramatically with increasing concentrations (Fig .4A). The reduction of live cells was concentration-dependent in cells treated with the scorpion venom. In comparison, effects of the venom on HUVEC-21 cell apoptosis were not significant, only the early apoptotic cells were increased (Fig .4B). This study ascertains that apoptosis is the main model of cell death induced by this agent in KYSE-510 cells. 

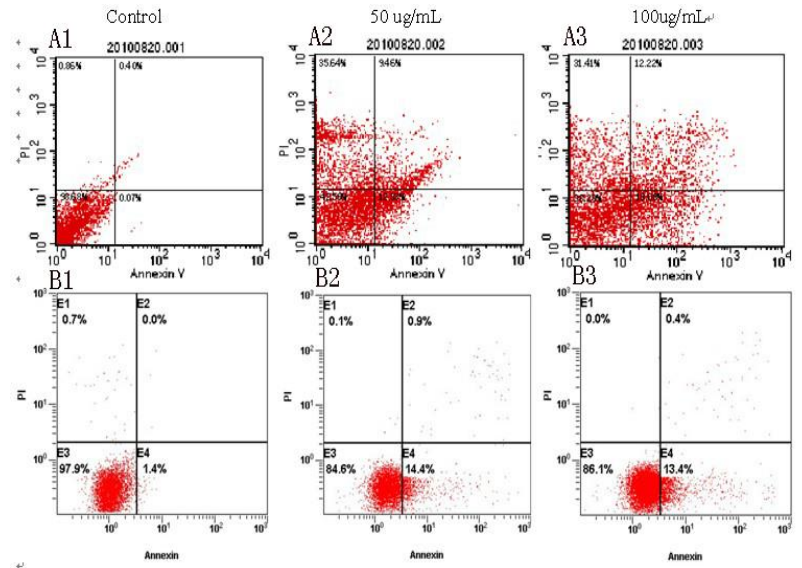

Figure 4. Flow-cytometric analysis of KYSE-510 and HUVEC-21 cells stained with Annexin V-FITC/PI. KYSE-510 cancer cells treated with $0 \mathrm{ug} / \mathrm{ml}$ (control)(A1), $50 \mathrm{ug} / \mathrm{mL}$ (A2) and 100 $\mathrm{ug} / \mathrm{mL}(\mathrm{A} 3)$ scorpion venom for $48 \mathrm{~h}$ were analyzed and compared to HUVEC-21 non-cancer cells treated for $48 \mathrm{~h}$ with $0 \mathrm{ug} / \mathrm{ml}$ (B1), 50 $\mu \mathrm{g} / \mathrm{mL}$ (B2) BMK and $100 \mu \mathrm{g} / \mathrm{mL}$ (B3) scorpion venom. Quadrants E1 - damaged cells, E2 - late apoptotic/secondary necrotic cells, E3-live cells, E4 - early apoptotic cells

\section{E. Calculating p21 and Caspase-3 mRNA expression with RT-PCR}

To investigate the cell cycle arrest and apoptosis in KYSE-510 cells, p21 and caspase- 3 mRNA levels in the cells treated for $48 \mathrm{~h}$ with the indicated concentrations of scorpion venom were analyzed using RT-PCR. The results suggested that the expression of p21 increased after $48 \mathrm{~h}$ of incubation with the venom (Fig .5A). On the contrary, the venom treatment had not significant effect on the expression of caspase-3 in the mRNA level after $48 \mathrm{~h}$ of incubation. (Fig .5B).

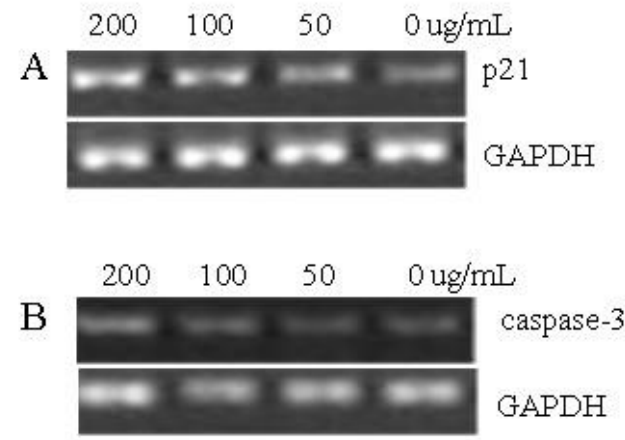

Figure 5. RT-PCR analysis of p21 (A) and caspase 3 (B) mRNA levels in KYSE-510 cells treated with the indicated concentrations of the scorpion venom

\section{F. Effects of spider venom on the expression of 21 and caspase-3 protein}

In order to explain the pathway resulting to apoptosis, we examined the activation of p21 and caspase- 3 protein. 21 binds to and inhibits CDK activity, preventing phosphorylation of critical CDK substrates and blocking cell cycle progression. Caspase-3 is a cytosolic protein found in cells as an inactive $32 \mathrm{kDa}$ proenzyme, and it is activated by proteolytic cleavage into two active subunits only when cells undergo apoptosis, which was reported to initiate apoptosis upon various stimuli. KYSE-510 cells treated with the scorpion venom $(0,50,100$ and $200 \mu \mathrm{g} / \mathrm{mL})$ for $48 \mathrm{~h}$ were analyzed for the protein level by Western blot. p21 and caspase-3 levels in KYSE-510 cells were different after that. After $48 \mathrm{~h}$ treatment, the levels of both proteins were enhanced significantly $(\mathrm{P}<0.05)($ Fig .6).
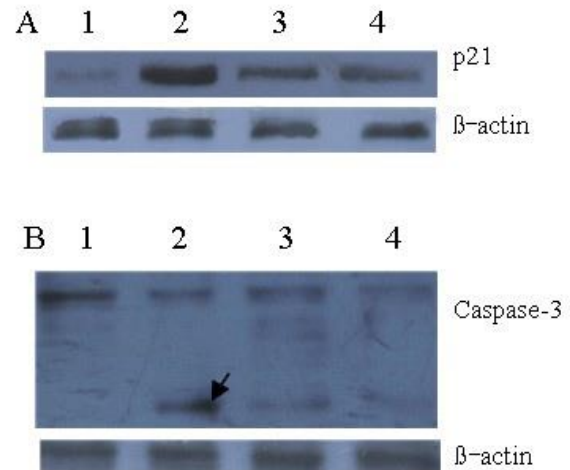

Figure 6. Western blot analysis of the effect of scorpion venom on the levels of $\mathrm{p} 21$ and caspase- 3 protein in KYSE-510 cells after treatment for $48 \mathrm{~h}$. As an internal control, $B$-actin protein was blotted concurrently. p21 (A) and casepase 3 (B) levels in control group (lane 1) and in the scorpion venom treatment groups (200 ug/L, lane 2;

$100 \mathrm{ug} / \mathrm{L}$, lane 3; $50 \mathrm{mg} / \mathrm{L}$, lane 4). The arrow indicates a $17 \mathrm{Da}$ activated subunit of caspase- 3

\section{DISCUSSION}

Our study on scorpion venom with in vitro anti-tumor potential has led us to the identification of scorpion venom as a promising source of compounds with favorable bioactivity in vitro. Scorpion venom may contain hundreds of compounds with different pharmacological activities. Venoms from scorpions from the Buthidae family can induce human death. However, not all venom compounds are toxic to humans, especially the ones with high molecular masses [19]. Although we do not know what kinds of specific substances are working, the main bioactive components of extracts Heterometrus liangi venom are the one series of polypeptides. Crude venoms were used as a kind of Chinese traditional medicines.

Limitation of cell viability in treated cells with the scorpion venom was confirmed by results of cytotoxicity assays. MTT assay is used to determine cytotoxicity of potential medicinal agents for measuring the activity of enzymes that reduce MTT to formazan. In our study, Heterometrus liangi venom significantly induced inhibition of KYSE-510 cell growth in a dose- and time-dependent manner (TABLE I and Fig .1). It showed that the inhibitory effect of Heterometrus liangi venom on KYSE-510 cells was further confirmed.

FCM can be applied in accordance with cell apoptosis and necrosis occurred during a series of morphological and biochemical changes of apoptosis and necrosis. It involves PI/Annexin V-FITC staining [21-22] The staining does not cell fixation required, before PI staining and subsequent Annexin V-FITC staining to, distinguish necrotic and apoptotic cells. FCM analysis showed that with the increase in toxin concentration $(0$, $100,200 \mu \mathrm{g} / \mathrm{mL})$, the diploid KYSE-510 cells increased. 
Sub G0/G1 peak is more obvious and the apoptosis rate increased. Meanwhile, with the toxin concentration increased, the normal cells decreased. The results showed statistically significant difference $(\mathrm{P}<0.05)$, suggesting that a certain concentration of endotoxin has also induced apoptosis and necrosis. The changes in KYSE-510 cell apoptosis and necrosis rate could be detected by FCM. The results showed that the venom experimental group also induced KYSE-510 cell apoptosis and necrosis. The results of detection method and the morphological observation from electron microscopy are consistent with the conclusion that the toxin affects on cell growth and death in KYSR-510 cells. After incubation with the venoms for $24 \mathrm{~h}$ and $48 \mathrm{~h}$, proliferation of KYSE-510 cells was inhibited. Furthermore, the venom incubation also promoted cell apoptosis and necrosis, a possible anti-tumor mechanism leading to KYSE-510 cell death.

This study was designed to explore the molecular mechanism of venom effect on the KYSE-510 apoptosis by examing a cell cycle related gene p21 and an apoptosis related gene caspase- 3 at both transcription and translation levels. At gene transcription level, the venom treatment increased p 21 mRNA expression in a dose dependent manner $(\mathrm{P}>0.05)$ while it had no effect oncaspase-3 mRNA level. Effect of gene is through the protein product to execute its function. Thus, we used Western-blot to analyze the protein levels of p21 and caspase- 3 in the venom-treated cells. Western-blot results showed that both p21 and caspase- 3 protein levels in the venom-treated KYSE-510 cells was significantly increased although they are not at exactly the same ratio. It is possible that scorpion toxin by increased caspase-3 by phosphatase dephosphorylation leaving the level of enhanced content, thereby stimulating caspase- 3 activity, so that the expression of Caspase-3 protein levels increased. We applied RT-PCR and Western-blot methods to analyze gene and protein level, because simply detecting the mRNA level cannot fully reflect the effect of venom on tumor cell appotosis. Protein function is the executor of oncology management. Cells with toxin, changed the expression of caspase-3 protein levels [23-24], but the transcription of caspase-3 was not affected, just changed its phosphorylation state, indicating that this regulation is a post-translational regulation.

This paper was based on the gene and protein expression level to investigate the mechanism of KYSE-510 cell apoptosis induced by scorpion venom directly.

\section{REFERENCES}

[1] Dyer N, 1999. Venom: Miracle Medicine [M]. Science World

[2] Wang R, Moreau P, Deschamps A, de Champlain J, Sauve R, Foucart S, Bai L, Lu XR.. Cardiovascular effects of Buthus martensii (Karsch) scorpion venom [J]. Toxicon, 1994;32(2):191-200.

[3] Kuhn-Nentwig L. Antimicrobial and cytolytic peptides of venomous arthropods [J]. Cell Mol Life Sci, 2003;60(12):2651-68.

[4] Wang CG, He XL, Shao F, LiuW, LingMH,Wang DC, Chi CW. Molecular characterization of an anti-epilepsy peptide from the scorpion Buthus martensi Karsch [J]. Eur J Biochem, 2001;268(8):2480-5.
[5] Torres-Larios A.Gurrola GB, Zamudio FZ, Possani LD. Hadrurin a new antimicrobial peptide from the venom of scorpion Hadrurus aztecus [J].Eur J Biochem, 2000;267(16):5023-31.

[6] Wang WX, Ji YH. Scorpion venom induces glioma cell apoptosis in vivo and inhibits glioma tumor growth in vitro $[\mathrm{J}] . \mathrm{J}$ Neurooncol, 2005;73(1):1-7.

[7] Zhang YY, Wu LC,Wang ZP, Wang ZX, Jia Q, Jiang GS, Zhang WD. Anti-proliferation effect of polypeptide extracted from scorpion venom on human prostate cancer cells in vitro [J]. J Clin Med Res, 2009;1(1): 24-31.

[8] Das Gupta S, Debnath A, Saha A, Giri B, Tripathi G, Vedasiromoni JR, Gomes A, Gomes A. Indian black scorpion (Heterometrus bengalensis Koch) venom induced antiproliferative and apoptogenic activity against human leukemic cell lines U937 and K562 [J]. Leuk Res, 2007;31(6): 817-25.

[9] Zargan J, Sajad M, Umar S, Naime M, Ali S, Khan HA. Scorpion (Odontobuthus doriae) venom induces apoptosis and inhibits DNA synthesis in human neuroblastoma cells [J]. Mol Cell Biochem, 2011;384(1-2):173-81.

[10] Wang ZM, Zhang WD. Progress of Scorpion venom and its extracts in immune regulation $[\mathrm{J}]$. China Journal of Chinese Materia Medica, 2008;33(2) :218-20.

[11] Petricevich VL. Effect of Tityus serrulatus venom on cytokine production and the activity of murine macrophages [J]. Mediators Inflamm, 2002;11(1):23-31.

[12] Petricevich VL, Lebrun I.. Immunomodulatory effects of the Tityus serrulatus venom on murine macrophage functions in vitro [J]. Mediators Inflamm, 2005;2005(1):39-49.

[13] Bagdáany M, Batista CV, Valdez-Cruz NA, et al. Anuroctoxin, a new scorpion toxin of the $\alpha$-KTx 6 subfamily, is highly selective for Kv1.3 over IKCa1 Ion Channels of Human T Lymphocytes [J]. Mol Pharmacol, 2005;67(4):1034-44.

[14] Zhu MS,Song DX. A Checklist of Scorpions from China (Arachnida:Scorpiones) [J]. Acta Arachnologica Sinica, 2004;13(2):111-118.

[15] Shimada Y, Imamura M, Wagata T, Yamaguchi N, Tobe T. Characterization of 21 Newly Established Esophageal Cancer Cell Lines [J]. Cancer, 1992;70(1):206.

[16] Situ ZhQ, Wu ZJ. Cell Culture. Book World Publications [M], 2004: 57-80, 200- 201,211-212.

[17] Mosmann T.. Rapid colorimetric assay for cellular growth and survival: application to proliferation and cytotoxicity assays $[\mathrm{J}]$. J Immunol Methods, 1983;65(1-2):55-63.

[18] Decker T, Lohmann-Matthes ML. A quick and simplemethod for the quantitation of lactatedehydrogenase release in measurements of cellular cytotoxicity and tumor necrosis factor (TNF) activity [J]. J Immunol Methods, 1988;115(1):61-9.

[19] Vermes I, Haanen C, Steffens-Nakken H, Reutelingsperger C. A novel assay for apoptosis. Flow cytometric detection of phosphatidylserine expression on early apoptotic cells using fluorescein labelled annexin $\mathrm{V} \quad[\mathrm{J}]$. J Immunol Methods, 1995;184(1):39-51.

[20] D'Suze G, Rosales A, Salazar V, Sevcik C. Apoptogenic peptides from Tityus discrepans scorpion venom acting against the SKBR3 breast cancer cell line [J]. Toxicon, 2010;56(8):1497-505.

[21] Abe R, Ueo H, Akiyoshi T. Evaluation of MTT assay in agarose for chemosensitivity testing of human cancers: comparison with MTT assay [J]. Oncology, 1994;51(5): 416-25.

[22] Darzynkiewicz Z, Bedner E, Smolewski P. Flow cytometry in analysis of cell cycle and apoptosis [J]. Semin Hematol, 2001;38(2): 179-93

[23] Wising C, Azem J, Zetterberg M, Svensson LA, Ahlman K, Lagergard T. Induction of apoptosis/necrosis in various human cell lineage by Haemophilus ducreyi cytolethal distending toxin. Toxicon, 2005;45(6):767-76.

[24] Gartel AL, Tyner AL. The role of the cyclin-dependent kinase inhibitor p21 in apoptosis. Mol Cancer Ther, 2002;1(8): 639-49.

[25] Qi H, Chen HZ, Jin ZJ. Caspase-3 gene expression and $\left[\mathrm{Ca}^{2+}\right] \mathrm{i}$ homeostasis underlying desipramine-induced C6 glioma cell apoptosis. Acta Pharmacol Sin, 2002; 23(9): 803-7. 